\title{
Development of A Small-Scale Indigenous Shea Butter Processing Plant in Nigeria: A Review
}

\author{
Gana IM ${ }^{1 *}$, Shehu $\mathrm{AA}^{2}$ and Balami $\mathrm{AA}^{2}$ \\ ${ }^{1}$ Department of Agricultural and Bio-environmental Engineering, Nigeria \\ ${ }^{2}$ Department of Agricultural and Bioresources Engineering, Nigeria
}

ISSN: 2640-9208

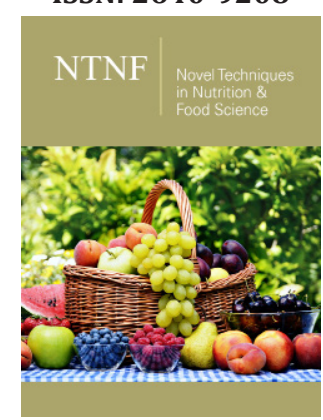

*1 Corresponding author: Gana IM, Department of Agricultural and Bioenvironmental Engineering, Nigeria

Submission: 海July 05, 2019

Published: 賎August 30, 2019

Volume 4 - Issue 3

How to cite this article: Gana IM, Shehu AA, Balami AA. Development of A SmallScale Indigenous Shea Butter Processing Plant in Nigeria: A Review. Nov Tech Nutri Food Sci. 4(3).NTNF.000588.2019. DOI: 10.31031/NTNF.2019.04.000588

Copyright@ Gana IM, This article is distributed under the terms of the Creative Commons Attribution 4.0 International License, which permits unrestricted use and redistribution provided that the original author and source are credited.

\begin{abstract}
The increase demand of shea butter and its product globally has contributed immensely in its traditional household and small-scale production in countries where it is present. This production method is laborious, time consuming and tedious. Also, the shea butter obtained is of low grade and quality as result of contamination from either the type of equipment used, or the processing method adopted. In other to address all these shortcomings a small-scale mechanized shea butter production plant was developed. The plant is made up of the following machines; sheller, crusher, steam roaster, miller and mixer. The development of this plant has mechanized the major unit operations of shea butter production. It has made easier and faster processing of shea butter and thus, serves as a training center for local processors and a catalyst for the development of shea butter industry in Nigeria. It can bring improvement in the productivity of the shea butter to meet up with local and international demands. The developed plant produced $0.45 \mathrm{~kg}$ of shea butter from $1 \mathrm{~kg}$ of shea nut and processed $12.5 \mathrm{~kg}$ of shea paste in $10 \mathrm{~min}$. It has input and throughput capacities of $600 \mathrm{~kg}$ of shea nut and $270 \mathrm{~kg}$ of shea butter respectively, in 8 hours operational time per day. The total cost of establishment of the plant is $\$ 2650$.
\end{abstract}

Keywords: Crushing; Milling; Mixing; Shea butter; Shelling; Plant; Roasting

\section{Introduction}

The increase awareness of shea butter's socio-economic and health benefits, as well as its increase demand globally as an important ingredient in personal care and edible products [1] has contributed immensely in increasing the number of its processors both at household and small-scale levels. In most of the developing countries like Nigeria shea butter is mostly processed using traditional manual method. This traditional method of extraction of shea butter from the kernel had been reported by Aviara et al. [2] to involve a series of unit operations. These operations include shelling or cracking of the shell using stone or by gently pounding the nuts with a mortar or pestle. According to, Gana et al. [3], in Nigeria, mostly shea nuts shelling is been done manually by rural women and children, which is time consuming and tedious. Also, the locally available machines are not having a cleaning unit, and this resulted to manual cleaning of the shelled nut. The shelled kernel is then broken into small pieces for roasting. This is done using either two stones or piston and mortal, it is also very tedious and time consuming [4]. Crushed shea nut pieces are roasted using cylindrical container made of mild steel with handle on open fire. This is where the slight smoky smell of traditional shea butter originates. According to Shehu et al. [5] most of the existing equipment for processing of shea butter especially the roasters is made of mild steel materials.

The mild steel can easily become rusted and cause contaminant of the product. Metal particles form as a result of the rusting settlement at the bottom of the equipment, thus causing contamination of the product. Smoke from open fire can result in contamination of the Polycyclic Aromatic Hydrocarbon (PAHS), some of which are said to be highly carcinogenic [6]. In addition, open fire roasting has the disadvantage of producing burnt crushed kernels which in turn leads to black shea oil formation and loss of vital and essential nutrients [7]. After the roasting, the roasted shea kernels can cool down for at least $30 \mathrm{~min}$ or at most 1 hour, before being milled in a milling machine into a fine paste. The next stage is the mixing or oil extraction, this is the most complex operation in the production process. It involves the following stages; mixing the paste with water, beating the paste with a palm of the hand, adding further small quantities of water, and gathering the floating fat. 
The mixing process serve two main purposes that is to release the fat from the ground mass and remove as much of the brown colour as possible from the brown mass and produce a clean fat [5]. Moreover, the manual method of mixing used by women in Nigeria is very tedious. Most often the container holding the paste is placed on the ground; women stand over the bucket and bend at the waist. Not only is mixing by hand tedious and time consuming, but the bending can cause strain on the back, making the process only suitable for younger women and exposes product to further contamination. The few existing mixing machines are only available in large scale industries which are sophisticated to handle and maintain by the local processors. To address this shortcoming a shea nut processing plant was developed at the Federal Polytechnic Bida.

\section{Processing center layout}

The shea butter processing plant at the Federal Polytechnic Bida has the following five main sections. Shea nut shelling and separation areas: this is the area where the shelling of the shea nut and separation of the broken shelled from the kernel takes place.

a) Shea kernel crushing area: this is the section were the shelled kernels are crushed into smaller sizes for further processing.

b) Steam roasting area: this is the section where the roasting of the crushed kernel takes place. The boiler generates steam and delivered it to the roasting chamber where the roasting takes place.

c) Milling unit: this is where the size reduction of the roasted kernel takes place. The size reduction is achieved using a hammer mill powered by a $15 \mathrm{hp}$ electric motor.

d) Mixing or oil extraction area: this is where the fine kernel is mixed with water to form a paste. The paste is being fed into the mixer where the oil is being extracted.

\section{Mode of operation of the production plant}

Dried shea nut is cleaned by removing all foreign material. The nut is then fed into the shelling machine were the shell is broken and separated from the kernel. The kernel is being reduced to smaller sizes with the aid of the crusher. The crushed nuts are then roasted with steam inside the developed steam roaster. The kernel roaster is a cylindrically shaped vessel made of stainless-steel plate with three separate compartments that include the roasting chamber, steam chamber, and insulator chamber. Crushed kernel is poured into the roasting chamber through the hopper or inlet. The steam chamber receives the heat from incoming steam and heat up the outer wall surface of the roasting chamber. After a few minutes, when the chamber has heated up, stirring of the crushed kernels begins by rotating the paddle carrying shaft through the rotating handle with the aid of gear arrangement. This constant stirring and heat application bring about uniform roasting of kernels. The roasted crushed kernels are then discharge into the collection pan through the roasted outlet. The roasted shea kernel is reduced into finer sizes by milling using the developed milling machine. The milled shea kernel was then mixed with water to form shea paste.
The paste is fed into the mixing container; cold water was added intermittently to the paste. As the machine blade rotates, it mixes the paste with water. Mixing continued with addition of small amount of cold water from time to get a smoother texture. This process was continued until the fat begins to break away from the cake (this is indicated by the colour of the mixture from chocolate to milk chocolate). At this stage cold or warm water is added depending on the temperature of the environment. A more quantity of cold-water is then pours into the mixture and stirred continuously to cause a grey, oily scum to rise. The water draining tap was then open and water with lesser density than the oil was drain out of the mixer through the tap. Fat was also collected into the boiling/heating container. Fat collected is immediately boiled in the boiling/heating container to complete the separation of fat from the cake. Boiling is continued until separation occurs and then oil is drained through the tap into a container and allows settling down for $30 \mathrm{~min}$. Heat supply from the combustion unit is temporary cut off to allow for clean-up of the cake residues that settled under the oil in the bottom of the heating tank in the form of a thick brown paste. The oil was retrieved into the clean heating tank where it was boiled to dehydrate the fat completely on a gentle heat and monitored closely to remove floating particles and dirty foam with ladle. The warm liquid fat or oil was then filtered through the tap using the ordinary thick cotton materials and finally collected on a plastic container and allowed to cool down and solidify. Wooden ladle was used to stirred Shea oil into a smooth and uniform texture when it begins to show signs of solidification or refrigerated immediately where it is available.

\section{Conclusion}

The Federal Polytechnic shea butter processing plant is the first complete indigenous processing plant that has been established in the Polytechnic after elaborate research work on the development of all components of the plant. The developed plant produced $0.45 \mathrm{~kg}$ of shea butter from $1 \mathrm{~kg}$ of shea nut and processed $12.5 \mathrm{~kg}$ of shea paste in $10 \mathrm{~min}$. It has input and throughput capacities of $600 \mathrm{~kg}$ of shea nut and $270 \mathrm{~kg}$ of shea butter respectively, in 8 hours operational time per day. The total cost of establishment of the plant is $\$ 2650$. The local processors can acquire this technology through their cooperative society, community groups or NGO's. The development and establishment of the plant overcome some of the major challenges associated with the traditional method of shea butter production in Nigeria. Also, it will improve the quality and quantity of the butter produced.

\section{References}

1. Bello BJ, Lovett PN, Pittendrigh BR (2015) The evolution of shea butter's paradox of paradoxa and the potential opportunity for information and communication technology (ICT) to improve quality, market access and women's livelihoods across rural Africa. Sustainability 7(5): 5752-5772.

2. Aviara N, Oluwole F, Haque M (2005) Effect of moisture content on some physical properties of sheanut (Butyrospernum paradoxum). Int Agrophys 19(3): 193-198.

3. Gana IM, Shehu AA, Dauda SM, Ahmad D (2016) Design, fabrication and testing of shea nut shelling machine. International food research journal 23(Suppl): S71-S79. 
4. Olaoye JO (2012) Development status of production and processing machinery of shea oil from a woody oil plant in Nigeria. International journal of science and engineering technology 3(5): 107-115.

5. https://seet.futminna.edu.ng/departments/Agriculture_and_BioResources_Engineering/

6. Ajai (2011) Determination of polycyclic aromatic hydrocarbon content using different extraction and instrumental methods in selected smoked fish species in Niger state, Thesis submitted to Department of Chemistry FUT, Minna, Nigeria.

7. Orhevba BA, Chuwu O, Osunde ZD, Oguagwu V, Gbabo A, et al. (2013) Design development and testing of a neem seed steam roaster. Innovative systems design and engineering 4(11): 11-17. 